\title{
STRENGTHENING PRECIPITATES IN ARGON ATOMIZED PM ALLOY 625
}

\author{
Frank J. Rizzo \\ Crucible Compaction Metais \\ 1001 Robb Hill Road \\ Oakdale, Pennsylvania 15071
}

\begin{abstract}
The argon atomized powder metal version of alloy 625 (i.e., PM A625) exhibits a unique feature of being precipitation hardenable with conventional heat treatments. This aging response results from the precipitation of gamma double prime and other phases which are not normally found in conventional cast and wrought alloy 625 . Some earlier work ${ }^{(1,2)}$ at Crucible has been reported at previous technical conferences. This paper is an update of the most recent work to determine the relationships of thermal treatment, microstructure, and mechanical properties.
\end{abstract}

\footnotetext{
Superalloys 718, 625, 706 and Various Derivatives Edited by E.A. Loria
}

The Minerals, Metals \& Materials Society, 1994 


\section{Introduction}

Because PM A625 can be age hardened, it has served a need for a good corrosion resistant material with yield strength capability from $414 \mathrm{MPa}(60 \mathrm{ksi})$ to $724 \mathrm{MPa}(105 \mathrm{ksi})$ for use in the Oil and Gas Industry. For these critical service applications it is also necessary to maintain a high level of ductility (i.e., a minimum of $35 \%$ reduction of area in a room temperature tensile test) which is a good indicator of stress corrosion cracking resistance in sour gas environments. It was previously shown ${ }^{(2)}$ that PM A625 exhibits a microstructure different from that of its conventional compositional counterpart. This difference can be attributed to the rapid solidification which occurs during the powder atomization process. Powder materials are far more homogeneous than conventionally produced cast and wrought alloys. The variations are more pronounced in a composition like 625 because of the total alloying content. In addition, secondary phases such as carbides are restricted in their size by the powder particle size which is less than $500 \mathrm{~m} \mu$ for most applications.

PM A625 consistently achieves $517 \mathrm{MPa}$ (75 ksi) (API specification 6A Type III strength) and higher yield strengths through precipitation hardening with conventional short time solution plus aging heat treatments. The corrosion resistance of the alloy at these higher strength levels is as good as that of its conventional low strength counterpart. An additional advantage of the powder version of the alloy is the ability to produce product forms such as monolithic near-net shapes, mill forms and clad or bimetallic parts with the higher strength and without the need for cold working.

\section{Background}

The work ${ }^{(2,3)}$ done previously followed the powder microstructurally through the process from atomization through consolidation to final thermal processing. It showed that PM A625 powder particles exhibited no surface films and little or no satelliting (i.e, particle attachment to each other). Electrolytic extraction of secondary phases from loose powder resulted in three sizes of precipitates in the residues along with some undissolved matrix. The largest size extract contained a Laves-type phase. The medium and fine sized extracted precipitates were both made up of the Laves-type phase and a Ti-rich MC carbide. This is summarized in Table $\mathrm{l}$. These precipitates were chemically extracted from the interdendritic regions on the powder surfaces. An analysis of the powder particle crosssections resulted in the same findings.

TABLE I. - SECONDARY PHASES IN PM A625

\begin{tabular}{|c|c|c|c|c|}
\hline \multirow{2}{*}{$\begin{array}{c}\text { Material } \\
\text { Form }\end{array}$} & \multicolumn{3}{|c|}{ Phases Present in Extracted Residues of Size: } & \multirow{2}{*}{ Comments } \\
\hline & Large & Medium & Fine & \\
\hline Loose Powder & Laves & $\begin{array}{c}\text { Laves } \\
\text { Ti-rich MC }\end{array}$ & $\begin{array}{l}\text { Laves } \\
\text { Ti-rich MC }\end{array}$ & $\begin{array}{c}\text { Some residual } \\
\text { matrix in all }\end{array}$ \\
\hline $\begin{array}{c}\text { As-HIP } \\
\text { Consolidated }\end{array}$ & Nb-rich MC & & $\begin{array}{c}\text { Ti-rich MC } \\
\text { Al-rich oxide }\end{array}$ & No Laves \\
\hline $\begin{array}{c}\text { As-HIP } \\
\text { Consolidated } \\
\text { Blend C }\end{array}$ & $\mathrm{Nb}$-rich $\mathrm{MC}$ & $\mathrm{M}_{0} \mathrm{C}$ & $\begin{array}{c}\text { Ti-rich MC } \\
\text { Al-rich oxide }\end{array}$ & No Laves \\
\hline Solution Treated & Nb-rich MC & & $\begin{array}{c}\text { Ti-rich MC } \\
\text { Al-rich oxide }\end{array}$ & $\begin{array}{c}\text { Nb-rich MC } \\
\text { goes into } \\
\text { solution at } \mathrm{T} \geq \\
927^{\circ} \mathrm{C}\left(1700^{\circ} \mathrm{F}\right)\end{array}$ \\
\hline Aged & Nb-rich MC & & $\begin{array}{c}\text { Ti-rich MC } \\
\text { Al-rich oxide } \\
\text { Very fine } \gamma^{\prime \prime}\end{array}$ & $\begin{array}{c}\text { No } \gamma^{\prime}, \text { delta no } \\
\text { secondary } \\
\text { carbide }\end{array}$ \\
\hline
\end{tabular}


Material was examined after HIP (i.e., hot isostatic pressing) consolidation to a fully dense solid and showed that different precipitates are present after this thermal processing than in the loose powder. For material that was not properly processed, the prior powder particle surfaces exhibited Al-rich oxide films which resulted in low ductilities and generally poor mechanical and corrosion properties. Material processed properly, showed a precipitation of discrete particles on the prior powder particle surfaces which were identified as MC carbides. A SEM photograph showing these precipitates is presented in Figure 1. Extracted residues identified three distinct precipitates in the as-HIP material: 1) a coarse Nbrich MC carbide formed during consolidation, 2) a fine Ti-rich MC carbide which is the same as that identified in the loose powder hence formed during solidification, and 3) a very fine Al-rich oxide (probably $\mathrm{Al}_{2} \mathrm{O}_{3}$ ) also formed during consolidation. There was no indication in consolidated product of the Laves-type phase present in the loose powder. Likewise, there were no other precipitates present in the as-HIP microstructure. This information is also presented in Table I.

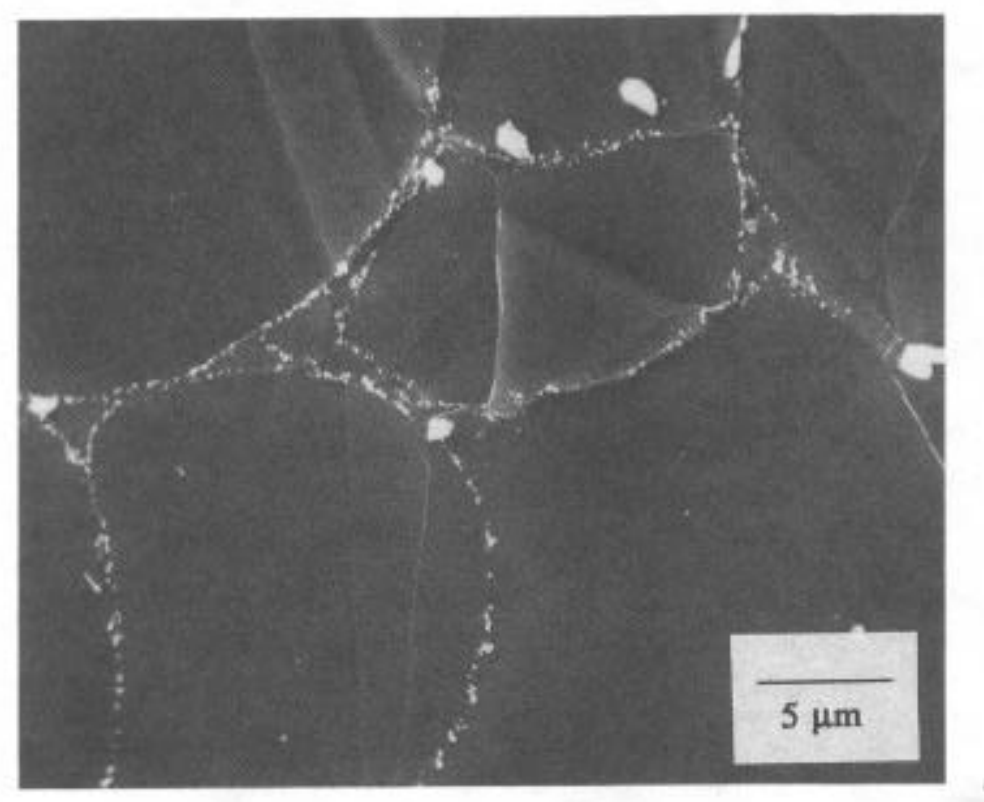

\section{Figure 1. SEM Photograph of As-HIP PM A625 Material Showing the Presence of MC Carbides. Etchant: $10 \% \mathrm{HCl}$ in Methanol Electrolytic}

One blend (i.e., Blend C) of PM A625 material exhibited an $\mathrm{M}_{6} \mathrm{C}$ carbide after HIP consolidation in addition to the other phases found in all of the other blends. This was thought to result from its higher carbon content (i.e., $0.026 \%$ ). Since the properties of this blend were below standard, it was concluded that carbon should be kept on the low side to avoid the precipitation of $M_{5} C$. A solution treatment study of this blend of material showed that the $\mathrm{M}_{5} \mathrm{C}$ could be dissolved at about $1093^{\circ} \mathrm{C}$ $\left(2000^{\circ} \mathrm{F}\right)$. The result was an improvement in ductility. The large Nb-rich MC carbides which form during consolidation in all blends started to solution at about $927^{\circ} \mathrm{C}\left(1700^{\circ} \mathrm{F}\right)$ and were completely solutioned at $1260^{\circ} \mathrm{C}\left(2300^{\circ} \mathrm{F}\right)$. However, progressive solutioning of these $\mathrm{Nb}$-rich MC carbides appeared to have a negative effect on strength and ductility.

Since this alloy is typically used in the age hardened condition, some extraction work was done after aging. Those phases present after consolidation were still in the microstructure and there was an indication of some very fine (i.e., $\leq 20 \mathrm{~nm}) \gamma^{*}\left(\mathrm{Ni}_{3} \mathrm{Nb}\right)$ precipitates, but there was no $\gamma^{\prime}$ (Ni,Al), delta phase, or any other carbide which is common in the cast and wrought version of this alloy. Early transmission electron microscopy work ${ }^{(3)}$ indicated that $\gamma^{*}$ was the only precipitate forming during the aging cycle and the particles ranged from 8 to $15 \mathrm{~nm}$ in size. 


\section{Carbon Content Optimization Study}

Since the early work ${ }^{(2)}$ indicated that control of the proper carbide precipitates was important to get reproducible material properties for PM A625, Crucible made a series of laboratory size heats with varying carbon content to optimize its effect on microstructure and properties. The chemical analyses of these heats is shown in Table II. The as-HIP microstructures ${ }^{(4)}$ of these variations exhibited increased carbide precipitation with increasing carbon content as shown in Figure 2. The data generated on the consolidated material from these heats are presented in Table III. The precipitation hardening response was sluggish at best for the lowest carbon level (i.e., Heat 518-645). While each of the other three heats gave a similar aging response, Heat L20 with the highest carbon content (i.e., $0.016 \% \mathrm{C}$ ) exhibited a slightly better combination of strength and ductility.

TABLE II. - PM A625 HEAT CHEMISTRIES FOR CARBON VARIATION STUDIES

\begin{tabular}{||c|c|c|c|c|}
\hline \multirow{2}{*}{$\begin{array}{c}\text { Weight Percent } \\
\text { for: }\end{array}$} & L.18 & L19 & L20 & $518-645$ \\
\cline { 2 - 5 } & $\mathrm{C}$ & 0.008 & 0.016 & 0.004 \\
$\mathrm{O}$ & 0.009 & 0.010 & 0.011 & 0.009 \\
$\mathrm{~N}$ & 0.010 & 0.002 & 0.003 & 0.003 \\
$\mathrm{Cr}$ & 0.002 & 20.46 & 20.39 & 21.10 \\
$\mathrm{Mo}$ & 20.56 & 8.85 & 8.87 & 8.79 \\
$\mathrm{Nb}$ & 8.82 & 3.94 & 4.05 & 3.82 \\
$\mathrm{Ti}$ & 3.94 & 0.23 & 0.22 & 0.28 \\
$\mathrm{Al}$ & 0.22 & 0.31 & 0.34 & 0.16 \\
$\mathrm{~S}$ & 0.28 & 0.001 & 0.002 & 0.001 \\
$\mathrm{Si}$ & 0.002 & 0.01 & 0.02 & $<0.01$ \\
$\mathrm{Mn}$ & 0.01 & $<0.02$ & $<0.02$ & $<0.02$ \\
$\mathrm{P}$ & $<0.02$ & 0.010 & 0.010 & 0.010 \\
$\mathrm{Fe}$ & 0.010 & 1.44 & 1.43 & 1.52 \\
$\mathrm{Ni}$ & 1.43 & Balance & Balance & Balance \\
\hline
\end{tabular}

TABLE III. - ROOM TEMPERATURE TENSILE PROPERTIES OF PM A625 WITH CARBON VARIATIONS

\begin{tabular}{|c|c|c|c|c|c|c|}
\hline $\begin{array}{l}\text { Heat } \\
\text { Code }\end{array}$ & $\begin{array}{l}\text { Carbon } \\
\text { Content (\%) }\end{array}$ & $\begin{array}{l}\text { Aging } \\
\text { Treatment }\end{array}$ & $\begin{array}{c}\text { UTS } \\
\mathrm{MPa}(\mathrm{ksi})\end{array}$ & $\begin{array}{l}0.2 \% \text { YS } \\
\mathrm{MPa}(\mathrm{ksi})\end{array}$ & $\begin{array}{l}E L \\
\%\end{array}$ & $\begin{array}{l}\text { RA } \\
\%\end{array}$ \\
\hline $\begin{array}{c}\text { 518-645 } \\
" \\
"\end{array}$ & $\begin{array}{c}0.004 \\
" \\
"\end{array}$ & $\begin{array}{l}1150^{\circ} \mathrm{F} / 4 \mathrm{hrs} / \mathrm{WQ} \\
1200^{\circ} \mathrm{F} / 4 \mathrm{hrs} / \mathrm{WQ} \\
1240^{\circ} \mathrm{F} / 4 \mathrm{hrs} / \mathrm{WQ}\end{array}$ & $\begin{array}{l}926(134.3) \\
949(137.7) \\
978(141.9)\end{array}$ & $\begin{array}{l}501(72.6) \\
534(77.4) \\
572(82.9)\end{array}$ & $\begin{array}{l}50.0 \\
49.5 \\
45.0\end{array}$ & $\begin{array}{l}59.2 \\
58.2 \\
56.4\end{array}$ \\
\hline $\begin{array}{l}\mathrm{L} 19 \\
" \\
"\end{array}$ & $\begin{array}{c}0.008 \\
" "\end{array}$ & $\begin{array}{l}1150^{\circ} \mathrm{F} / 4 \mathrm{hrs} / \mathrm{WQ} \\
1200^{\circ} \mathrm{F} / 4 \mathrm{hrs} / \mathrm{WQ} \\
1240^{\circ} \mathrm{F} / 4 \mathrm{hrs} / \mathrm{WQ}\end{array}$ & $\begin{array}{c}964(139.9) \\
1027(148.9) \\
1087(157.7)\end{array}$ & $\begin{array}{c}551(79.9) \\
627(90.9) \\
706(102.4)\end{array}$ & $\begin{array}{l}48.5 \\
44.0 \\
39.0\end{array}$ & $\begin{array}{l}56.8 \\
52.9 \\
48.9\end{array}$ \\
\hline $\begin{array}{l}\mathrm{L} 18 \\
" \\
"\end{array}$ & $\begin{array}{c}0.009 \\
" \\
"\end{array}$ & $\begin{array}{l}1150^{\circ} \mathrm{F} / 4 \mathrm{hrs} / \mathrm{WQ} \\
1200^{\circ} \mathrm{F} / 4 \mathrm{hrs} / \mathrm{WQ} \\
1240^{\circ} \mathrm{F} / 4 \mathrm{hrs} / \mathrm{WQ}\end{array}$ & $\begin{array}{c}959(139.1) \\
1024(148.5) \\
1091(158.3)\end{array}$ & $\begin{array}{l}534(77.4) \\
621(90.1) \\
709(102.9)\end{array}$ & $\begin{array}{l}46.5 \\
46.0 \\
38.5\end{array}$ & $\begin{array}{l}56.4 \\
51.5 \\
43.4\end{array}$ \\
\hline $\begin{array}{l}\mathrm{L} 20 \\
" 1 \\
"\end{array}$ & 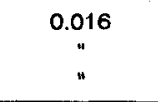 & $\begin{array}{l}1150^{\circ} \mathrm{F} / 4 \mathrm{hrs} / \mathrm{WQ} \\
1200^{\circ} \mathrm{F} / 4 \mathrm{hrs} / \mathrm{WQ} \\
1240^{\circ} \mathrm{F} / 4 \mathrm{hrs} / \mathrm{WQ}\end{array}$ & $\begin{array}{c}964(139.8) \\
1022(148.3) \\
1088(157.8)\end{array}$ & $\begin{array}{l}531(77.0) \\
617(89.5) \\
692(100.4)\end{array}$ & $\begin{array}{l}50.0 \\
48.0 \\
41.0\end{array}$ & $\begin{array}{l}60.0 \\
54.7 \\
45.8\end{array}$ \\
\hline \multicolumn{7}{|c|}{$\begin{array}{l}\text { Notes: 1. All specimens were solution treated at } 996^{\circ} \mathrm{C}\left(1825^{\circ} \mathrm{F}\right) 1 \mathrm{hr} / \mathrm{WQ} \text {. } \\
\text { 2. All results represent the average of two tests. }\end{array}$} \\
\hline \multicolumn{2}{|c|}{$\begin{array}{l}1825^{\circ} \mathrm{F}=996^{\circ} \mathrm{C} \\
1150^{\circ} \mathrm{F}=622^{\circ} \mathrm{C}\end{array}$} & $\begin{array}{l}1200^{\circ} \mathrm{F}=649^{\circ} \mathrm{C} \\
1240^{\circ} \mathrm{F}=671^{\circ} \mathrm{C}\end{array}$ & & \multicolumn{3}{|c|}{ WQ $=$ Water Quench } \\
\hline
\end{tabular}




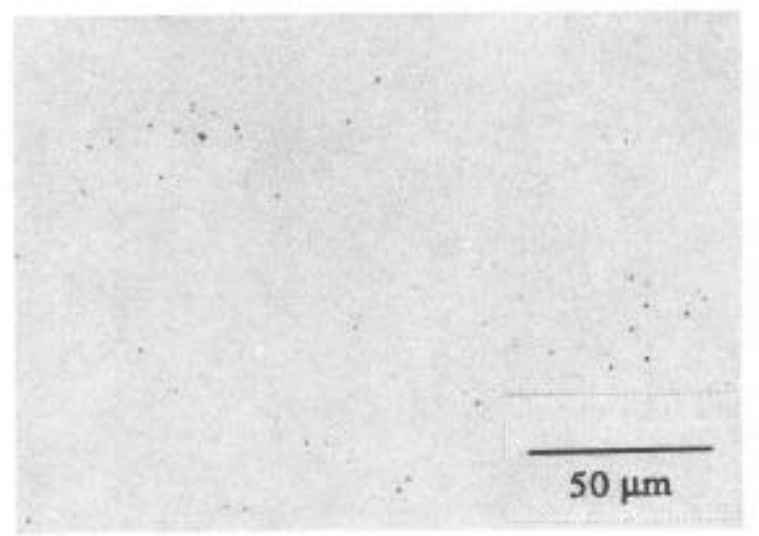

$0.004 \% \mathrm{C}$

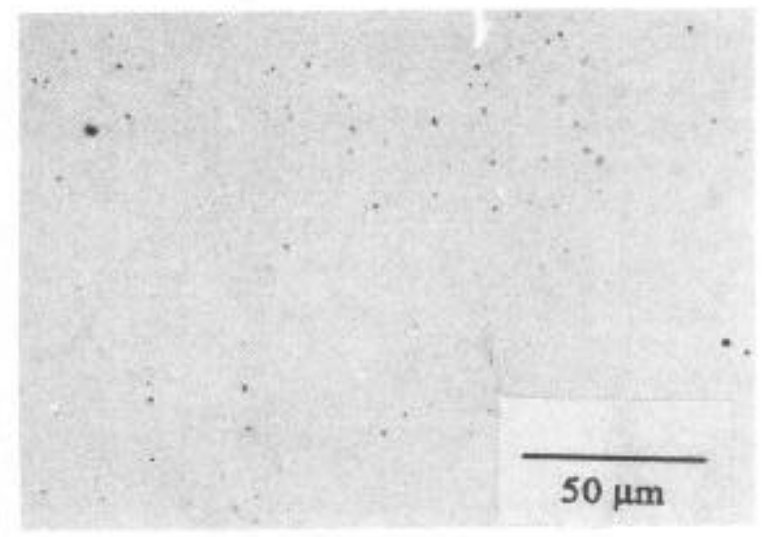

$0.009 \% \mathrm{C}$

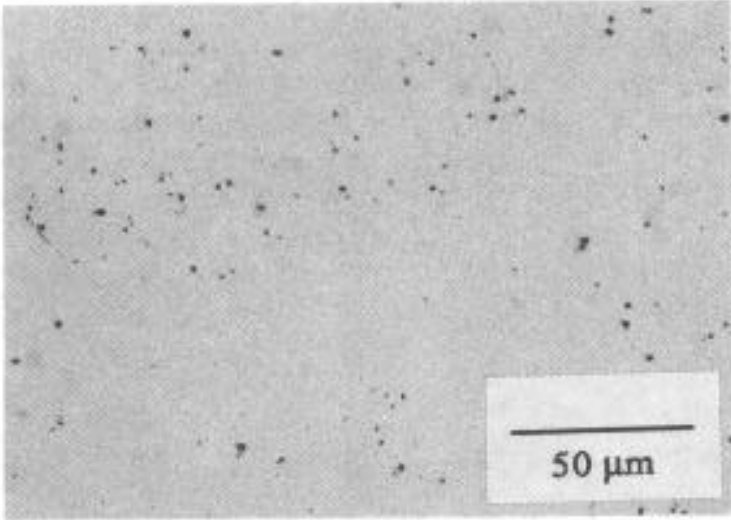

$0.016 \% \mathrm{C}$

Figure 2. Light Micrographs of PM A625 Showing Increased Carbide Precipitation with Increased Carbon Content. Etchant: $20 \% \mathrm{H}_{2} \mathrm{SO}_{4}$ in Methanol Electrolytic

Since it appeared that carbon has a role in the hardening ability of PM A625, a series of samples was prepared for transmission electron microscopy from room temperature tensile test bars in various heat treated conditions from production Blend 91IN511. The chemistry of this blend is shown in Table IV and its room temperature tensile properties are listed in Table V. The results show that the aging response for this blend of PM A625 was excellent. Acceptable strengths and ductilities were achieved with as little as four hours of aging.

TABLE IV. - CHEMISTRY OF PM A625 BLEND 91 IN511

\begin{tabular}{|c|c|c|c|c|c|c|c|c|c|c|c|c|c||}
\hline \multicolumn{10}{|c||}{ Weight Percent for: } \\
\hline C & $\mathbf{O}$ & N & Cr & Mo & Nb & TI & Al & S & SI & Mn & P & Fe & NI \\
\hline 0.016 & 0.008 & 0.007 & 21.49 & 8.88 & 3.77 & 0.20 & 0.25 & 0.002 & 0.00 & $<0.02$ & 0.008 & 1.30 & Bal \\
\hline
\end{tabular}


TABLE V. - ROOM TEMPERATURE TENSILE PROPERTIES OF PM A625 BLEND 91 IN511

\begin{tabular}{|c|c|c|c|c|}
\hline Aging Treatment & $\begin{array}{c}\text { UTS } \\
\text { MPA (ksi) }\end{array}$ & $\begin{array}{l}0.2 \% \text { YS } \\
\mathrm{MPa}(\mathrm{ksi})\end{array}$ & $\begin{array}{l}\text { EL } \\
\%\end{array}$ & $\begin{array}{l}\text { RA } \\
\%\end{array}$ \\
\hline AS-HIP & $942(136.7)$ & $489(70.9)$ & 50.0 & 54.4 \\
\hline $622^{\circ} \mathrm{C}\left(1150^{\circ} \mathrm{F}\right) / 4 \mathrm{hrs} / \mathrm{OQ}$ & $978(141.8)$ & $558(80.9)$ & 46.5 & 56.0 \\
\hline $649^{\circ} \mathrm{C}\left(1200^{\circ} \mathrm{F}\right) / 4 \mathrm{hrs} / \mathrm{OQ}$ & $1044(151.5)$ & $647(93.9)$ & 41.5 & 53.5 \\
\hline $671^{\circ} \mathrm{C}\left(1240^{\circ} \mathrm{F}\right) / 4 \mathrm{hrs} / \mathrm{OQ}$ & $1094(158.6)$ & $705(102.3)$ & 39.0 & 48.4 \\
\hline \multicolumn{5}{|c|}{$\begin{array}{l}\text { Notes: } \\
\text { 1. All Material except the as-HIP was solution treated at } 996^{\circ} \mathrm{C}\left(1825^{\circ} \mathrm{F}\right) / 1 \mathrm{hr} / \mathrm{OQ} \text {. } \\
\text { 2. All results represent the average of two tests. }\end{array}$} \\
\hline
\end{tabular}

The identification of precipitates in heat treated Blend 91IN511 was done with transmission electron microscopy ${ }^{(5)}$. A summary of the findings is presented in Table VI. The data on the as-HIP material verifies the extraction work ${ }^{(2)}$ conducted previously on production material. After consolidation, two types of $(\mathrm{Nb}, \mathrm{Ti}) \mathrm{C}$ and an Al-rich oxide were found. No $\gamma$ " was detected in the as-HIP condition. The larger ( $\mathrm{Nb}, \mathrm{Ti}) \mathrm{C}$ particles were approximately $80 \% \mathrm{Nb}$ and corresponded to the $\mathrm{Nb}$-rich $\mathrm{MC}$ found earlier in consolidated product. The finer MC was Ti-rich and contained about $60 \% \mathrm{Ti}$. It was found previously in both the powder and in the consolidated product. Figure 3 shows a TEM photograph of these carbides. The important finding of this investigation was the presence of an increasing amount of the Ti-rich MC with increasing aging temperature. In addition, the aged material showed a larger size and quantity of $\gamma^{\prime}$ with increasing aging temperature. In the previous work, the $\gamma^{\prime}$ was too fine to be resolved. Figure 4 is a TEM photograph showing these fine precipitate particles.

TABLE VI. - TEM OBSERVED MICROSTRUCTURAL FEATURES OF PM A625 BLEND 91 IN511

\begin{tabular}{|c|c|c|c|c|c|}
\hline $\begin{array}{c}\text { Material } \\
\text { Condition }\end{array}$ & Matrix & $\begin{array}{c}\left(\mathrm{Nb}_{0.8} \mathrm{Ti}_{0.2}\right) \mathrm{C} \\
\text { Carbide }\end{array}$ & $\begin{array}{c}\mathrm{Al}_{2} \mathrm{MgO}_{4} \\
\text { Oxide }\end{array}$ & $\begin{array}{c}\left(\mathrm{Ti}_{0.6} \mathrm{Nb}_{0.4}\right) \mathrm{C} \\
\text { Carbide }\end{array}$ & $\gamma^{\prime \prime}$ \\
\hline As-HIP & $\begin{array}{c}\text { Single Phase with } \\
\text { weak short range } \\
\text { order }\end{array}$ & $\begin{array}{l}\text { Large at prior } \\
\text { particle } \\
\text { boundaries }\end{array}$ & $\begin{array}{c}\text { Fine at prior } \\
\text { particle } \\
\text { boundaries }\end{array}$ & $\begin{array}{c}\text { Fine at prior } \\
\text { particle } \\
\text { boundaries } \\
\text { Few }\end{array}$ & None \\
\hline $621^{\circ} \mathrm{C}\left(1150^{\circ} \mathrm{F}\right) / 4 \mathrm{hrs}$ & $\begin{array}{l}\text { Weak } \gamma^{\prime \prime} \text { diffraction } \\
\text { spots } \\
\text { Low volume fraction }\end{array}$ & $\begin{array}{l}\text { Large at prior } \\
\text { particle } \\
\text { boundaries }\end{array}$ & $\begin{array}{c}\text { Fine at prior } \\
\text { particle } \\
\text { boundaries }\end{array}$ & $\begin{array}{c}\text { Fine at prior } \\
\text { particle } \\
\text { boundaries } \\
\text { More }\end{array}$ & $\begin{array}{l}\text { Few } \\
<3 \mathrm{~nm}\end{array}$ \\
\hline $649^{\circ} \mathrm{C}\left(1200^{\circ} \mathrm{F}\right) / 4 \mathrm{hrs}$ & $\begin{array}{l}\text { Strong } \gamma^{\prime \prime} \text { diffraction } \\
\text { spots } \\
\text { Increasing volume } \\
\text { fraction }\end{array}$ & $\begin{array}{l}\text { Large at prior } \\
\text { particle } \\
\text { boundaries }\end{array}$ & $\begin{array}{c}\text { Fine at prior } \\
\text { particle } \\
\text { boundaries }\end{array}$ & $\begin{array}{c}\text { Fine at prior } \\
\text { particle } \\
\text { boundaries } \\
\text { More }\end{array}$ & $\begin{array}{l}\text { More } \\
3-5 n m\end{array}$ \\
\hline $671^{\circ} \mathrm{C}\left(1240^{\circ} \mathrm{F}\right) / 4 \mathrm{hrs}$ & $\begin{array}{l}\text { Very strong } \gamma^{\prime \prime} \\
\text { diffraction spots } \\
\text { Further increased } \\
\text { volume fraction }\end{array}$ & $\begin{array}{l}\text { Large at prior } \\
\text { particle } \\
\text { boundaries }\end{array}$ & $\begin{array}{c}\text { Fine at prior } \\
\text { particle } \\
\text { boundaries }\end{array}$ & $\begin{array}{c}\text { Fine at prior } \\
\text { particle } \\
\text { boundaries } \\
\text { Many }\end{array}$ & $\begin{array}{l}\text { Many } \\
5-8 \mathrm{~nm}\end{array}$ \\
\hline
\end{tabular}

Note: Specimens, except for as-HIP, were solution treated at $996^{\circ} \mathrm{C}\left(1825^{\circ} \mathrm{F}\right) / 1 \mathrm{hr} / \mathrm{OQ}$ prior to aging 

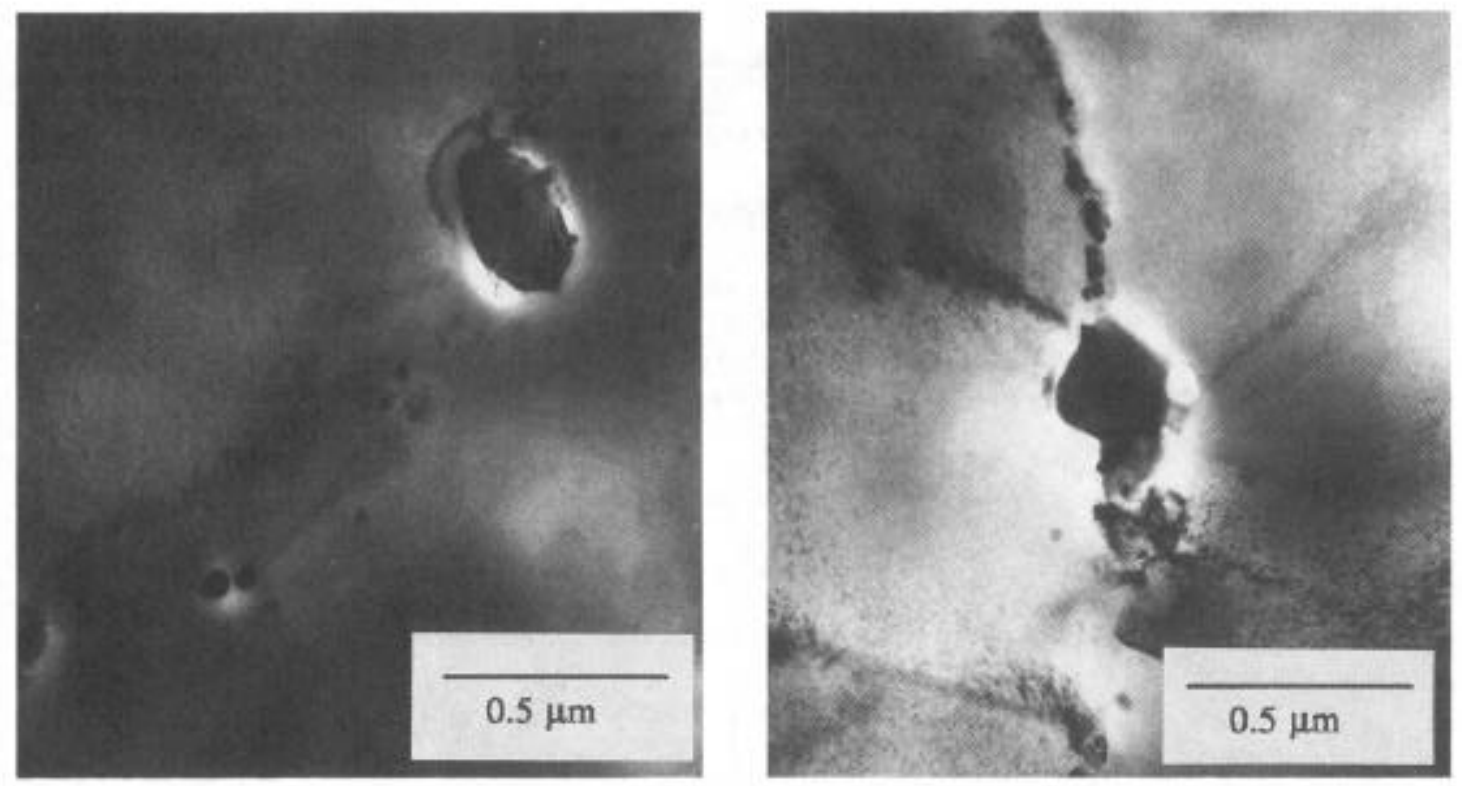

Figure 3. TEM Photograph Showing the Nb-Rich (Large) and the Ti-Rich (Small) MC Carbides in PM A625.

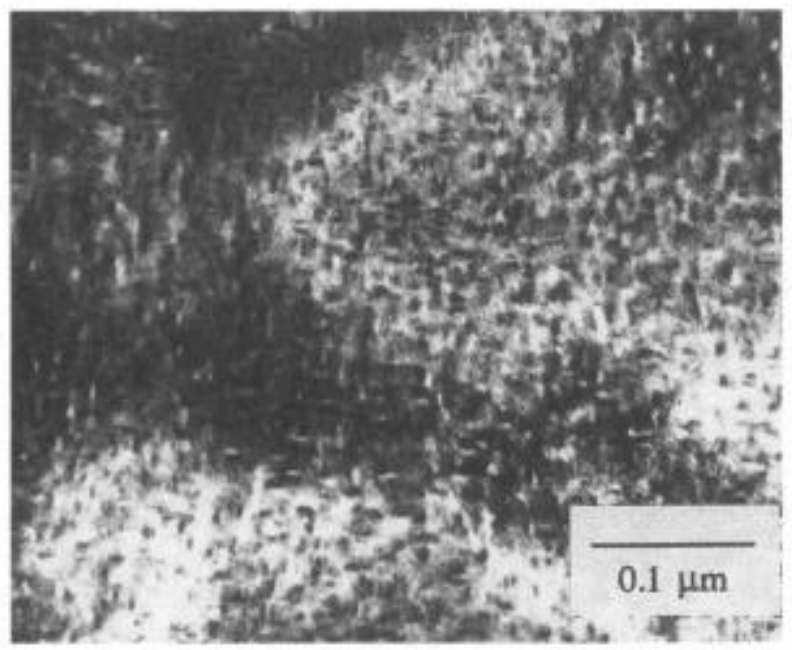

Figure 4. TEM photograph Showing the $\gamma^{\circ}$ Precipitates in PM A625 Aged at $671^{\circ} \mathrm{C}$ $\left(1240^{\circ} \mathrm{F}\right) / 4 \mathrm{hrs}$. 
There appears to be a contribution to the age hardening from the Ti-rich MC carbide as well as the $\gamma^{\prime \prime}$. There is an increased incidence of both phases with increased aging temperature and with the corresponding increased tensile and yield strengths. These results indicate that the elements involved in the secondary phase precipitation in PM A625 are: nioblum, titanium, aluminum, carbon, and nickel. As discussed above the effect of oxygen can be significant if the material is not processed properly. In this work, oxygen was maintained at its typical level.

\section{Further Chemistry Optimization Studies}

Four laboratory size heats were made to help understand the hardening contributions from titanium and aluminum. Table VII contains the chemical analyses of these heats. One heat (L130) had no titanium with the remainder of the composition intact to see the effect of no Ti-rich MC carbide precipitates. Another (L131) looked at a low level of titanium (i.e., $0.06 \%$ ) to determine if there is some minimum level that is acceptable. The third (L132A) was an evaluation of a no aluminum composition to investigate the effect of the Al-rich oxide precipitates.

TABLE VII. - PM A625 HEAT CHEMISTRIES FOR THE Ti AND AI VARIATION STUDY

\begin{tabular}{|c|c|c|c|}
\hline \multirow{2}{*}{$\begin{array}{c}\text { Weight Percent } \\
\text { for: }\end{array}$} & L130 & L131 & L132A \\
\cline { 2 - 4 } & 0.014 & 0.018 & 0.014 \\
$\mathrm{C}$ & 0.010 & 0.009 & 0.017 \\
$\mathrm{~N}$ & 0.002 & 0.002 & 0.001 \\
$\mathrm{Cr}$ & 21.34 & 21.18 & 21.27 \\
$\mathrm{Mo}$ & 8.64 & 8.57 & 8.66 \\
$\mathrm{Nb}$ & 3.77 & 3.57 & 3.52 \\
$\mathrm{Ti}$ & $<0.01$ & 0.06 & 0.20 \\
$\mathrm{Al}$ & 0.23 & 0.22 & $<0.01$ \\
$\mathrm{~S}$ & 0.002 & 0.001 & 0.001 \\
$\mathrm{Si}$ & $<0.01$ & $<0.01$ & $<0.01$ \\
$\mathrm{Mn}$ & $<0.02$ & $<0.02$ & $<0.02$ \\
$\mathrm{P}$ & 0.011 & 0.011 & 0.010 \\
$\mathrm{Fe}$ & 1.43 & 1.42 & 1.40 \\
$\mathrm{Ni}$ & Balance & Balance & Balance \\
\hline
\end{tabular}

The room temperature tensile properties of these modifications appear in Table VIII. The results show that when titanium is removed or kept to a minimum (L130 and L131), PM A625 cannot be effectively precipitation hardened. After 24 hours of aging at $671^{\circ} \mathrm{C}\left(1240^{\circ} \mathrm{F}\right)$ an increase in strength is observed, but the ductility drops off dramatically. This indicates that the Ti-rich MC which increases in amount with increased aging temperature in standard titanium material, contributes to both strength and ductility.

The no aluminum composition (L132A) also cannot be age hardened effectively in less than 24 hours at the highest aging temperature studied. It even exhibits lower as-HIP strength than any other PM A625 material examined in this work. The presence of the fine Al-rich oxide which apparently forms mostly at prior powder particle boundaries during the consolidation process adds to the as-HIP strength and takes part in the age hardening process in this material. Since the size or amount of the Al-rich oxides do not appear to change with aging treatment, the effect of this phase may be indirect. For example, the aluminum could be tying up the available oxygen and freeing the titanium to form the Ti-rich MC carbides. This has not yet been verified microscopically. Aluminum does not form $\gamma^{\prime}\left(\mathrm{Ni}_{3} \mathrm{Al}\right)$ to help strengthen. this alloy, since this phase was not found in any of materials evaluated. 
TABLE VIII. - ROOM TEMPERATURE TENSILE PROPERTIES OF PM A625 IN THE Ti AND AI VARIATION STUDY

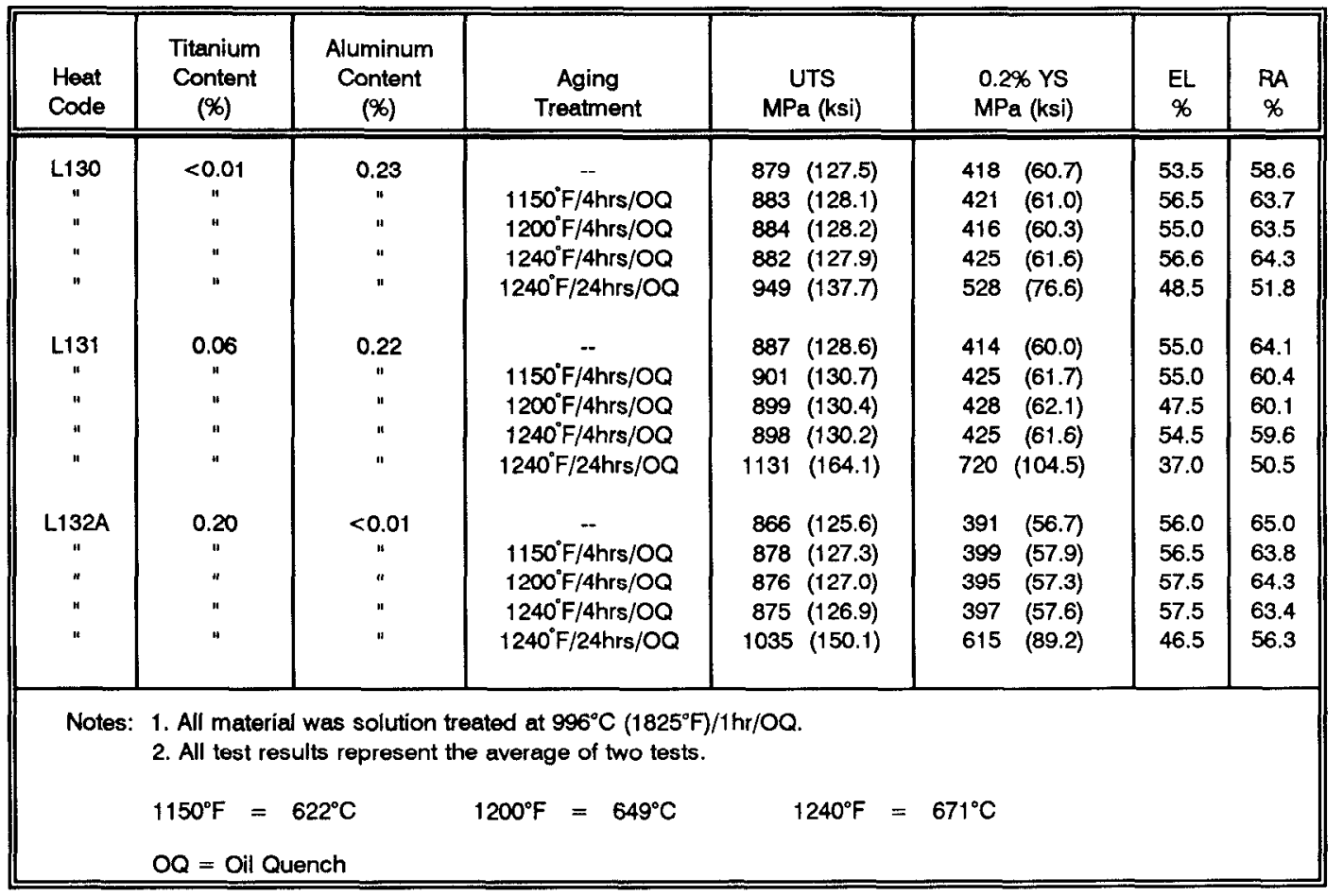

\section{$\underline{\text { Summary }}$}

The work to study the secondary phase precipitation in PM A625 is an on-going investigation at Crucible. To date, it has been determined that there are at least three microstructural constituents that contribute to the age hardening response of this material: $\gamma^{\prime}$, fine Ti-rich MC carbides, and fine Al-rich oxides. Large Nb-rich MC carbides are present in all of the consolidated and/or thermally processed material. They do not seem to add to or degrade the aging capability, but when they are solutioned, the strength and ductility are adversely effected. The presence of $\mathrm{M}_{6} \mathrm{C}$ carbides is detrimental to the properties of the material and can be avoided by keeping the carbon content low.

\section{Acknowledgements}

I would like to thank Dr. John Radavich of Purdue and Dr. Ragavan Ayer of STEM, Inc. for their work to identify the microstructural constituents in PM A625 material.

\section{References}

1. J. E. Stulga and B. J. McTiernan, "The Metallurgy and Applications of Rapidly Solidified Alloy 625" (Paper presented at the International Conference on Rapidly Solidified Materials, San Diego, California, 3-5 February 1985), 397.

2. F. J. Rizzo and J. F. Radavich, "Microstructural Characterization of PM 625-Type Materials" (Paper presented at Superalloys 718,625 and Various Derivatives, Pittsburgh, Pennsylvania, 23-26 June 1991). 
3. A. M. Dalley and C. C. Fisher, "TEM Investigation of PM Inconel 625 Alloys" (Report prepared by the RJ Lee Group, Inc. for Crucible Materials Corp., 6 June 1989).

4. M. C. Latona, "Microstructure of HIP PM Alloy 625 Compacts" (Internal memorandum prepared at Crucible Research Center, 18 October 1991).

5. R. Ayer, "Transmission Electron Microscopy (TEM) Analysis of PM Alloy 625" (Report prepared by STEM, Inc. for Crucible Materials Corp., 23 October 1991). 